\title{
Adapted Murine Sepsis Score: Improving the Research in Experimental Sepsis Mouse Model
}

\author{
Maicon Machado Sulzbacher ${ }^{(D,},{ }^{1,2,3}$ Lucas Machado Sulzbacher, ${ }^{1,2}$ Felipe Rafael Passos, ${ }^{1}$ \\ Bruna Letícia Endl Bilibio, ${ }^{1,2}$ Kauana de Oliveira, ${ }^{1}$ Wellington Felipe Althaus, ${ }^{1}$ \\ Matias Nunes Frizzo $\mathbb{D}^{1,2}$ Mirna Stela Ludwig $\mathbb{D}^{1,2}$ Ivana Beatrice Mânica Da Cruz, ${ }^{3}$ \\ and Thiago Gomes Heck (iD) $1,2,4$
}

\author{
${ }^{1}$ Research Group in Physiology, Regional University of Northwestern Rio Grande do Sul State (UNIJUÍ), Ijuí, RS, Brazil \\ ${ }^{2}$ Postgraduate Program in Integral Attention to Health (PPGAIS-UNIJUÍ/UNICRUZ), Ijuí, RS, Brazil \\ ${ }^{3}$ Postgraduate Program in Pharmacology, Federal University of Santa Maria (UFSM), Brazil \\ ${ }^{4}$ Postgraduate Program in Mathematical and Computational Modelling (UNIJUI), Brazil
}

Correspondence should be addressed to Maicon Machado Sulzbacher; maiconsulzbacher@hotmail.com and Thiago Gomes Heck; thiago.heck@unijui.edu.br

Received 17 June 2021; Revised 16 December 2021; Accepted 3 January 2022; Published 27 January 2022

Academic Editor: Mateusz Maciejczyk

Copyright (c) 2022 Maicon Machado Sulzbacher et al. This is an open access article distributed under the Creative Commons Attribution License, which permits unrestricted use, distribution, and reproduction in any medium, provided the original work is properly cited.

\begin{abstract}
The Murine Sepsis Score (MSS) is used to assess the severity of sepsis in rats and mice based on observational characteristics. The quantitative variables of glycemia, body weight, and temperature are predictors of severity in experimental models of sepsis. Therefore, our study sought to adapt the MSS with the same variables to indicate earlier the severity of the disease in murine models of the disease. Sepsis mice presented hypoglycemia, weight loss, and hypothermia. Therefore, these variables were included in the Adapted Murine Sepsis Score (A-MSS). The A-MASS presented 100\% specificity and $87.5 \%$ sensibility been able to differentiate the early sepsis symptoms and its severity. The A-MSS allows an early and more complete diagnosis of sepsis in mice and might be considered as a procedure to improve the analysis of systemic sepsis dysfunction in murine experimental models.
\end{abstract}

\section{Introduction}

Sepsis is a systemic infection characterized by multiple organ dysfunction and high mortality rates. Therefore, studies investigating the pathophysiology in sepsis are required [1, 2 ], and the use of experimental mouse models has been considered a fundamental approach [3], due to the physiological similarities between human and mice, including a great genotypic homology in terms of hormonal, cell signaling, receptors, immune system, and oxidative and cell stress responses [4]. The bacteria-induced sepsis in animal models has similar characteristics found in septic patients $[5,6]$ due to the gram-negative bacteria membrane endotoxins like lipopolysaccharide (LPS) and lipoteichoic acid (LTA) from gram-positive bacteria [7].
The pathogen-associated molecular patterns (PAMPS) are recognized by cell surface receptors, for example, Tolllike receptors, expressed by the human and animal leukocytes. In this way, LPS is recognized by the host cell defense by TRL4, whereas TLR2 receptors recognize LTA. Both molecular interactions induce the activation of the nuclear kappa B transcription factor (NF- $\kappa$ B), which initiates the synthesis of several proinflammatory cytokines. Also, these PAMPS may interact with platelets and endothelial tissue, adding microvascular complications that have an essential role in the inflammation and systemic dysfunction in sepsis [8].

One of the leading infectious focus in sepsis is abdominal origin. Staphylococcus aureus and Escherichia coli bacteria are commensals of the mouse gastrointestinal tract and can 


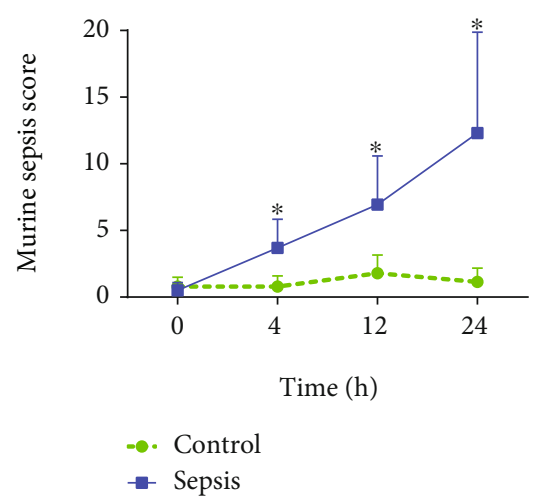

(a)

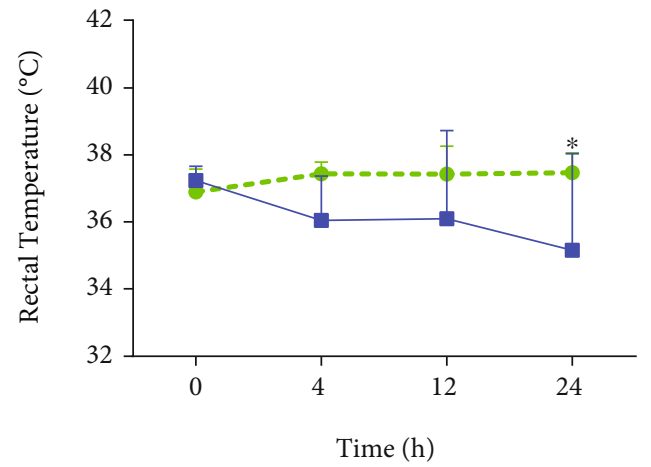

(c)

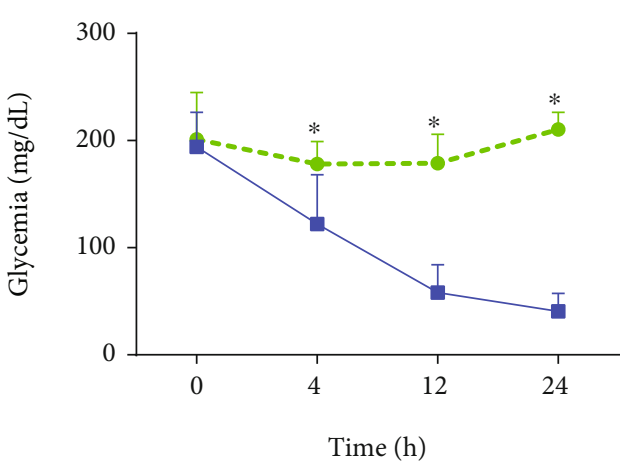

(b)

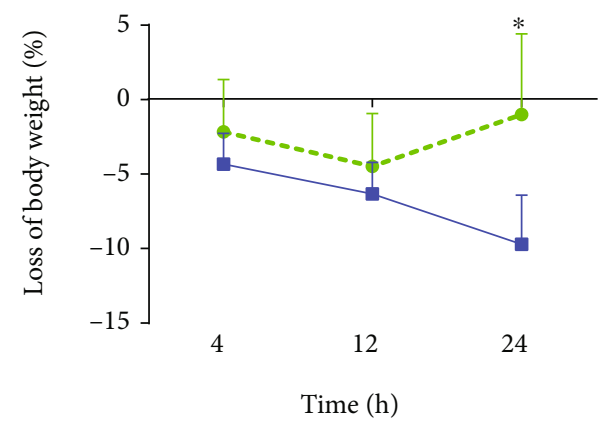

(d)

Figure 1: Measurement of Murine Sepsis Score (MSS) $\left({ }^{*} P<0.0001 ; F_{1.52}=31.43\right)$ (a), glycemia $\left({ }^{*} P<0.0001 ; F_{1.52}=124.3\right)(\mathrm{b})$, rectal temperature $\left({ }^{*} P<0.0001 ; F_{1.130}=8.23\right)(\mathrm{c})$, and body weight loss $\left({ }^{*} P<0.0002 ; F_{1.39}=16.95\right)$ (d) within 24 hours after induction of sepsis with $20 \%$ fecal solution $(1 \mathrm{mg} / \mathrm{g})$. Statistical analysis was performed by two-way ANOVA followed by Bonferroni posttest.

be found in the feces of these animals $[5,9]$. One of the leading infectious focus in sepsis is abdominal origin. Staphylococcus aureus and Escherichia coli bacteria are commensals of the mouse gastrointestinal tract and can be found in the feces of these animals [5, 9]. Therefore, an experimental model of sepsis is peritonitis induction by the intraperitoneal administration of the autogenous fecal solution. From this procedure, sepsis is recognized by an application of Murine Sepsis Score (MSS) that consists of observing and categorizing the level of consciousness, activity, behavior, response to stimuli, respiratory rate, and quality of breathing movements [10]. However, it is possible to observe a decreased glycemic levels, core temperature, and body weight loss if we follow up animals for 24 hours $[11,12]$, but these variables have not been included in the MSS protocol [10].

Patients and animals with sepsis may present hypothermia $[13,14]$, hypoglycemia $[11,15]$, body weight loss [16], and hematological alterations [17]. Also, early identification of sepsis is a well-known, relevant procedure to allow successful treatment of the disease [18]. Therefore, herein, we proposed an adaptation in the MSS (A-MSS) to provide a score that identifies sepsis in an experimental model in the initial stages.

\section{Material and Methods}

2.1. Animals. Fifteen male C57BL/6 mice aged 90 to 150 days from the Life Sciences Department (DCVida) of the North- western Regional University of Rio Grande do Sul State (UNIJUÍ) were used in this study.

2.2. Ethics Statement. The ethical principles established by the International Animal Protection Standards have been respected [19], Brazilian Code of Animal Experimentation-1988, as well as the National Institutes of Health (NIH) Guide to Laboratory Animal Care and Use. This study was approved by the Animal Use Ethics Committee of UNIJUÍ (CEUA 048/2016).

2.3. Experimental Design. The animals were divided into two experimental groups: control $(n=7)$ and sepsis $(n=8)$. A $20 \%$ fecal solution $(200 \mathrm{mg} / \mathrm{mL})$ was prepared with fresh stool in $0.9 \% \mathrm{NaCl}$, and it was administered at a dose of $5 \mu \mathrm{L} / \mathrm{g}$ ( $1 \mathrm{mg} / \mathrm{g}$, i.p.) in the sepsis group, while control animals received $0.9 \% \mathrm{NaCl}$ [12]. The animals were monitored for glycemia, blood count, rectal temperature, and MSS (Table S1), before (time zero) and at 4, 12, and 24 hours after sepsis induction.

2.4. Procedures Details. Glycemia was measured by distal tail puncture $(\sim 5 \mu \mathrm{L})$ using Optium Xceed ${ }^{\circledR}$ glucometer. Rectal temperature was measured with a digital thermometer, and body weight was measured using a semianalytical balance. For hematological analysis, blood was collected $(0,4,12$, and $24 \mathrm{~h})$ by caudal puncture $(10 \mu \mathrm{L})$. Samples were diluted 


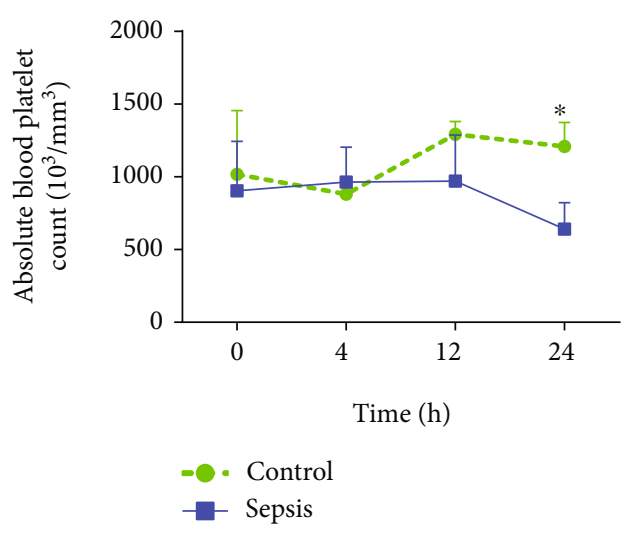

(a)

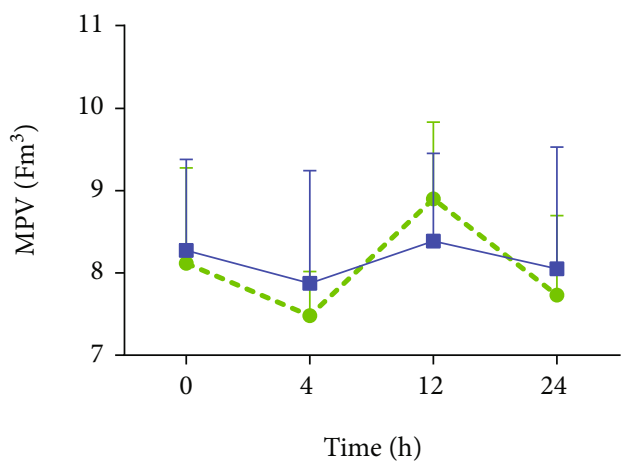

(c)

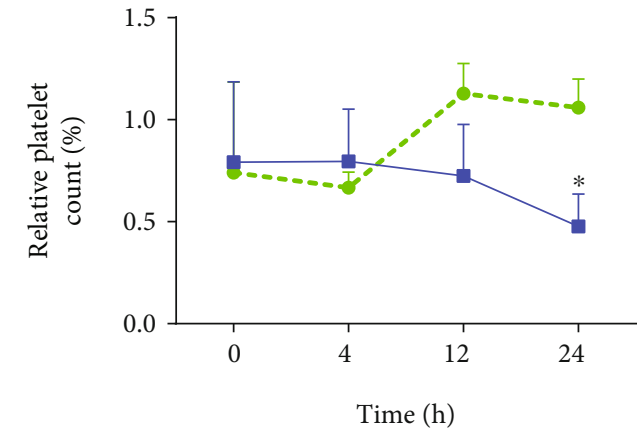

(b)

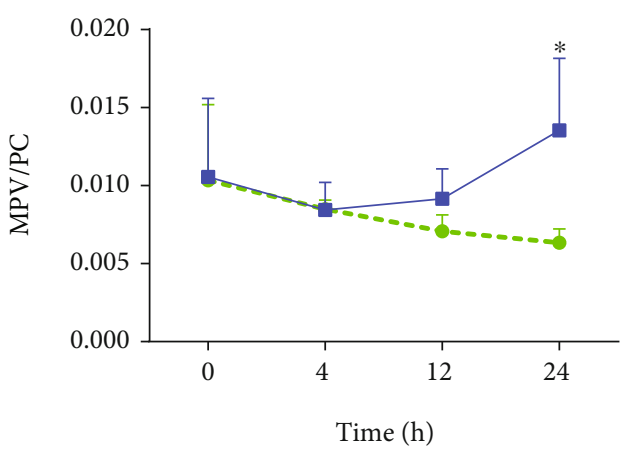

(d)

Figure 2: Absolute blood platelet count $\left({ }^{*} P=0.0021 ; F_{1.48}=10.53\right)(\mathrm{a})$, relative platelet count $\left({ }^{*} P=0.013 ; F_{1.40}=6.69\right)(\mathrm{b})$, mean platelet volume $(\mathrm{MPV})(P=0.6)(\mathrm{c})$, and MPV to platelet ratio (MPV/PC) $\left({ }^{*} P<0.0021 ; F_{1.48}=10.53\right)(\mathrm{d})$, within 24 hours after induction of sepsis with $20 \%$ fecal solution $(1 \mathrm{mg} / \mathrm{g})$. Statistical analysis was performed using two-way ANOVA followed by a Bonferroni posttest.

$1: 3$ with $0.9 \%$ saline and $1 \mu \mathrm{L}$ of anticoagulant (EDTA). Hematological strains were performed on the slide for differential leukocyte count, stained with a panoptic type [20].

2.5. Statistical Analysis. Data were analyzed using the Kolmogorov-Smirnov test. The results in which the evaluation was performed over time were verified by two-way ANOVA (time $\times$ treatment) followed by Bonferroni posttest. Spearman or Pearson correlation test was performed. The potential diagnosis of A-MSS within four hours after sepsis induction was tested by ROC curve. The cutoff point for A-MSS diagnosis was determined by observing the most appropriate balance between sensitivity and specificity in the ROC curve [21]. The significance level of 5\% $(P<0.05)$ was considered.

\section{Results}

The animals submitted to sepsis presented increased MSS $12 \mathrm{~h}$ and $24 \mathrm{~h}$ after fecal solution administration (Figure 1(a)). Also, animals with sepsis showed a decrease in glycemia, rectal temperature, and body weight (Figures 1(b)-1(d)). It was possible to verify that sepsis induces alterations in appearance, level of consciousness, activity, stimulus-response, eye aspect, and respiratory rate and quality (Supplementary Figure S1).
Sepsis was able to cause a decrease in absolute and relative platelet count (Figures 2(a) and 2(b)) without inducing mean platelet volume alterations (MPV) (Figure 2(c)) but increased the MPV to platelet ratio (MPV/PC) (Figure 2(d)).

The neutrophil count increased in $12 \mathrm{~h}$ after sepsis induction, then returning to basal level in the next 12 hours (Figure 3(a)). At 24h, we found a decrease in white blood cell count, including a decrease in lymphocyte and monocyte count (Figures 3(d), 3(b), and 3(c), respectively).

These alterations in immune cells, as well as observed in the platelets, impact in the neutrophil-lymphocyte ratio (NLR), which increased at $12 \mathrm{~h}$ together with the platelet to lymphocyte ratio (PLR) in $24 \mathrm{~h}$ (Figures $3(\mathrm{e})$ and $3(\mathrm{f})$, respectively).

A strong negative correlation $(r=-0.79)$ was observed between MSS and glycemia 24 hours after sepsis induction. Also, a moderate negative correlation was observed between MSS and body temperature $(r=-0.61)$ and weight loss $(r=-0.52)$ in the same time-point (Figures 4(a)-4(c)). Therefore, we proposed the A-MSS which was able to report sepsis within four hours of the sepsis induction (Figure 4(d)). When this score was evaluated from the ROC curve in this period, it was found that it can be used as a diagnostic standard (Figure 4(e)), from an A-MSS value of 3.5 , obtaining a sensitivity of $87.5 \%$ and specificity of $100 \%$. 


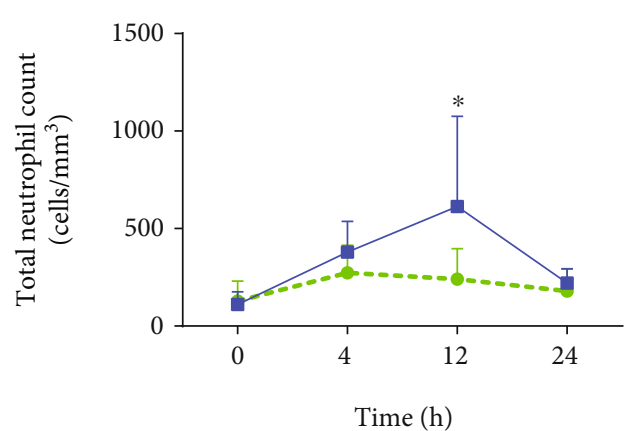

-๑ Control

$\rightarrow$ Sepsis

(a)

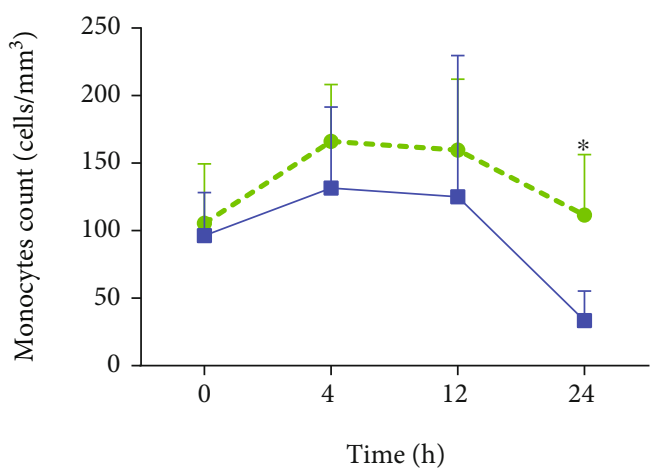

(c)

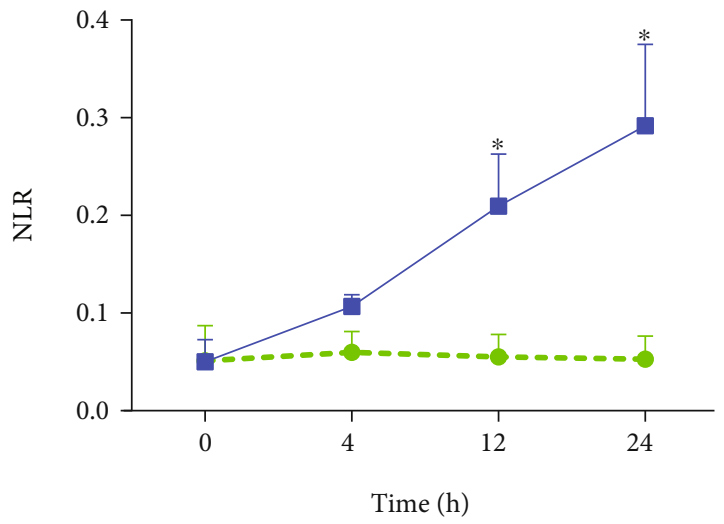

(e)

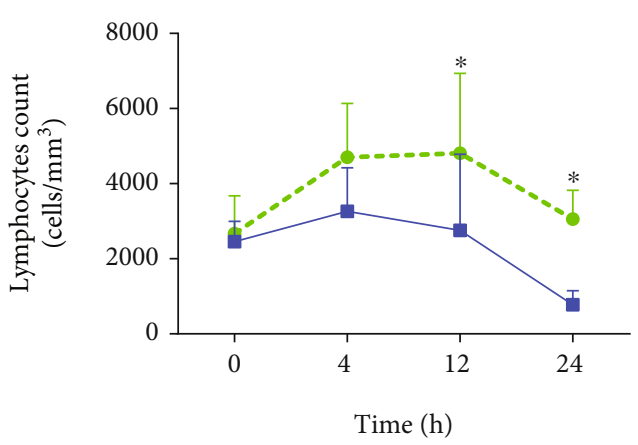

(b)

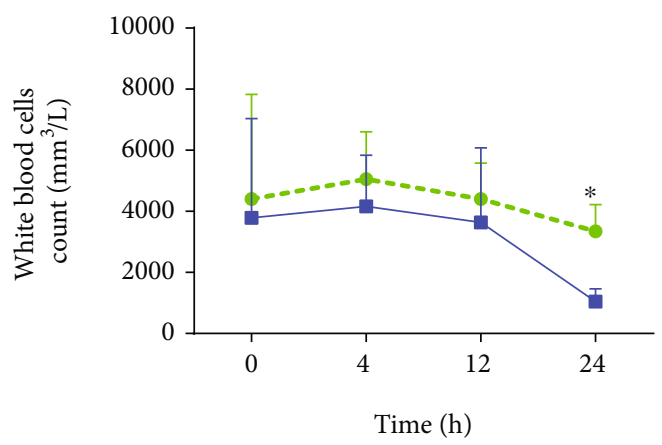

(d)

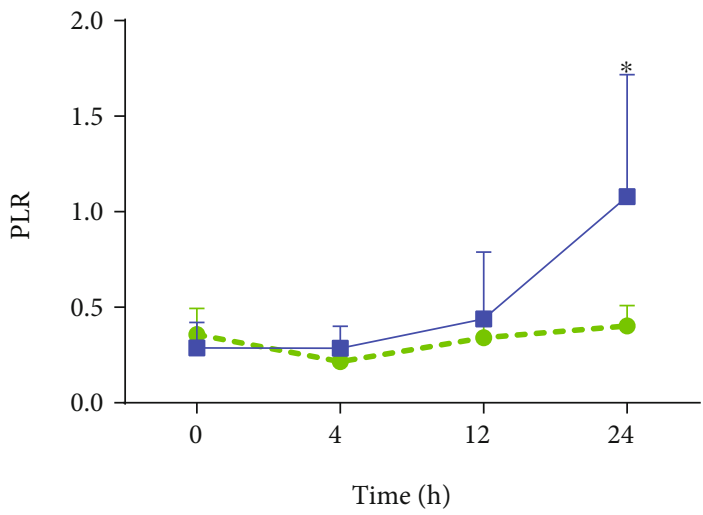

(f)

Figure 3: Total neutrophil count $\left({ }^{*} P=0.047 ; F_{1.40}=4.17\right)$ (a), lymphocyte count $\left({ }^{*} P=0.0002 ; F_{1.44}=16.62\right)$ (b), monocyte count $\left({ }^{*} P=0.024 ; F_{1.40}=5.47\right)(\mathrm{c})$, white blood cell count $\left({ }^{*} P=0.0021 ; F_{1.48}=3.34\right)(\mathrm{d})$, ratio between neutrophil-lymphocyte count (NLR) $\left({ }^{*} P<0.0001 ; F_{1.4}=76.05\right)(\mathrm{e})$, and platelet-lymphocyte ratio (PLR) $\left({ }^{*} P=0.031 ; F_{1.40}=4.95\right)(\mathrm{f})$, within 24 hours after induction of sepsis by $20 \%$ fecal solution $(1 \mathrm{mg} / \mathrm{g})$. Statistical analysis was performed using two-way ANOVA followed by Bonferroni posttest.

The proposed A-MSS is detailed in Table 1. A-MSS measured four hours after sepsis induction showed strong negative correlation with the severity marker parameters in experimental sepsis: lymphocyte count $(r=-0.79)$, white blood cells count $(r=-0.83)$, and platelet count $(r=-0.77)$ (Supplementary Figure S2A-C). Also, there was a strong positive correlation between A-MSS and NLR $(r=0.74)$ (Supplementary Figure S2D). There is no statistically significant correlation between A-MSS and platelet to lymphocyte ratio $(P>0.05)$ and also between A-MSS and $\mathrm{MPV} / \mathrm{PC}$ ratio $(P>0.05)$.

\section{Discussion}

We showed that the inclusion of variables easily measurable as glycemia, temperature, and body weight in the MSS may improve the research in sepsis mice model. Our proposal of A-MSS represents a sum of observations, and together 


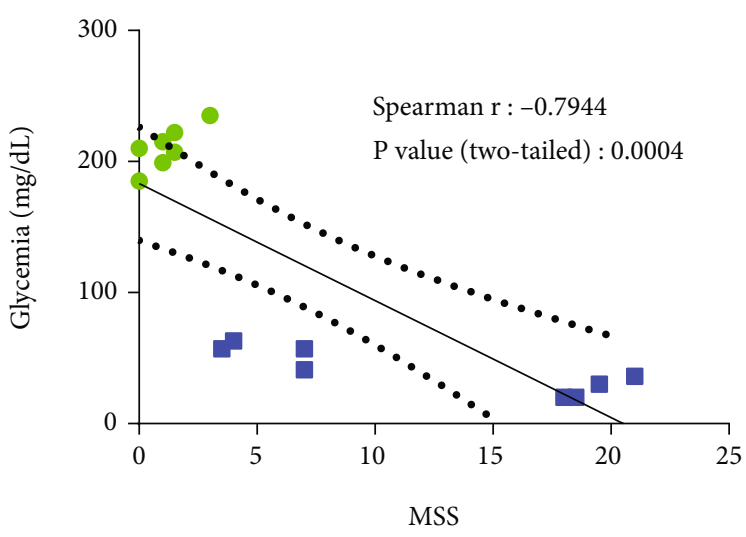

(a)

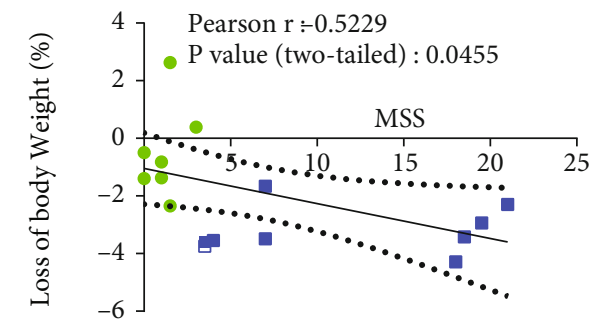

(c)

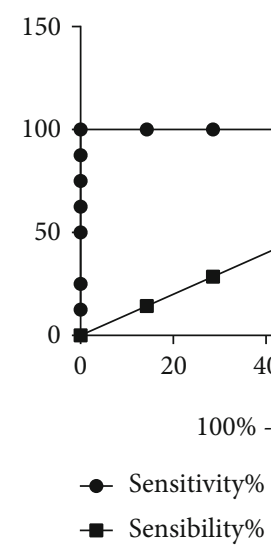

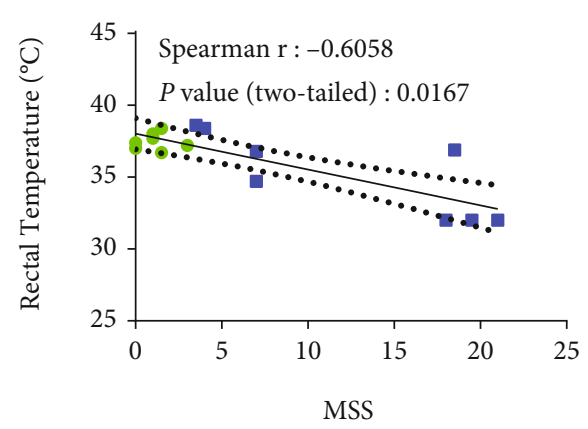

(b)

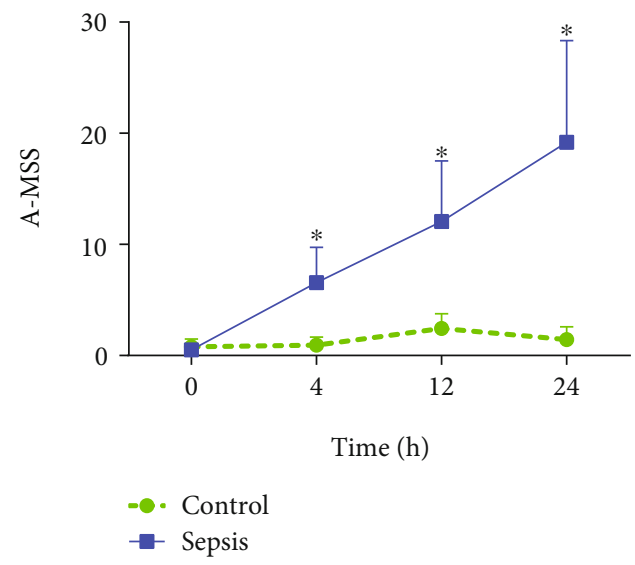

(d)

Area under th ROC curve : 1 $95 \%$ confidence interval : $1-1$ $P$ value $:<0.0001$

FIGURE 4: Correlation between MSS and glycemia (a), temperature (b) and relative weight loss (c), and 24 hours after sepsis induction and measurement of Adapted Murine Sepsis Score (A-MSS) throughout the experiment period $\left({ }^{*} P<0.0001 ; F_{1.52}=58.39\right)(\mathrm{d})$, and ROC curve (e) at time 4 hours after induction of sepsis with $20 \%$ fecal solution $(1 \mathrm{mg} / \mathrm{g})$. Statistical analysis was performed using two-way ANOVA followed by Bonferroni posttest (d) and curve ROC (e).

with the established MSS, the abovementioned variables might be considered as a new score for the evaluation of sepsis in experimental models (Table 1).

Sepsis is a complex disease that requires a complex form to diagnose it successfully [22]. The A-MSS added parameters to the MSS, which allowed an indirect assessment of the cardiovascular (temperature) and metabolic systems (glycemia and body weight), which are essential for the prognosis in sepsis in animals and humans. In humans, the diagnosis is made by measures of neurological, cardiovascular, respiratory, renal, hepatic, and platelet dysfunction, by the reproducible Sequential Organ Failure Assessment (SOFA) score [23]. We believe that A-MSS approximates the clinical variables evaluated in SOFA for the early diagnosis of sepsis in animal models.

The central nervous system dysfunction is mainly characterized by septic encephalopathy, followed by autonomic 
Table 1: Adapted Murine Sepsis Score (A-MSS).

\begin{tabular}{|c|c|c|c|c|c|}
\hline Score & 0 & 1 & 2 & 3 & 4 \\
\hline Appearance & Coat is smooth & $\begin{array}{l}\text { Patches of hair } \\
\text { piloerected }\end{array}$ & $\begin{array}{l}\text { Majority of back is } \\
\text { piloerected }\end{array}$ & $\begin{array}{l}\text { Piloerection may or } \\
\text { may not be present; } \\
\text { mouse appears } \\
\text { "puffy" }\end{array}$ & $\begin{array}{l}\text { Piloerection may or may } \\
\text { not be present; mouse } \\
\text { appears emaciated }\end{array}$ \\
\hline $\begin{array}{l}\text { Level of } \\
\text { consciousness }\end{array}$ & Mouse is active & $\begin{array}{c}\text { Mouse is active but } \\
\text { avoids standing } \\
\text { upright }\end{array}$ & $\begin{array}{c}\text { Mouse activity is } \\
\text { noticeably slowed. } \\
\text { The mouse is still } \\
\text { ambulant }\end{array}$ & $\begin{array}{l}\text { Activity is impaired. } \\
\text { Mouse only moves } \\
\text { when provoked; } \\
\text { movements have a } \\
\text { tremor }\end{array}$ & $\begin{array}{c}\text { Activity severely } \\
\text { impaired. Remains } \\
\text { stationary when } \\
\text { provoked, with possible } \\
\text { tremor }\end{array}$ \\
\hline Activity & $\begin{array}{l}\text { Normal amount of } \\
\text { activity. Mouse is any of } \\
\text { eating, drinking, } \\
\text { climbing, running, and } \\
\text { fighting }\end{array}$ & $\begin{array}{l}\text { Slightly suppressed } \\
\text { activity. Mouse is } \\
\text { moving around } \\
\text { bottom of cage }\end{array}$ & $\begin{array}{l}\text { Suppressed activity. } \\
\text { Mouse is stationary } \\
\text { with occasional } \\
\text { investigative } \\
\text { movements }\end{array}$ & No activity & $\begin{array}{c}\text { No activity. Mouse } \\
\text { experiencing tremors, } \\
\text { particularly in the hind } \\
\text { legs }\end{array}$ \\
\hline $\begin{array}{l}\text { Response to } \\
\text { stimulus }\end{array}$ & $\begin{array}{l}\text { Mouse responds } \\
\text { immediately to auditory } \\
\text { stimulus or touch }\end{array}$ & $\begin{array}{l}\text { Slow or no response } \\
\text { to auditory stimulus; } \\
\text { strong response to } \\
\text { touch (moves to } \\
\text { escape) }\end{array}$ & $\begin{array}{l}\text { No response to } \\
\text { auditory stimulus; } \\
\text { moderate response to } \\
\text { touch (moves a few } \\
\text { steps) }\end{array}$ & $\begin{array}{l}\text { No response to } \\
\text { auditory stimulus; } \\
\text { mild response to } \\
\text { touch (no } \\
\text { locomotion) }\end{array}$ & $\begin{array}{l}\text { No response to auditory } \\
\text { stimulus. Little or no } \\
\text { response to touch. } \\
\text { Cannot right itself if } \\
\text { pushed over }\end{array}$ \\
\hline Eyes & Open & $\begin{array}{c}\text { Eyes not fully open, } \\
\text { possibly with } \\
\text { secretions }\end{array}$ & $\begin{array}{c}\text { Eyes at least half } \\
\text { closed, possibly with } \\
\text { secretions }\end{array}$ & $\begin{array}{l}\text { Eyes half closed or } \\
\text { more, possibly with } \\
\text { secretions }\end{array}$ & Eyes closed or milky \\
\hline $\begin{array}{l}\text { Respiration } \\
\text { rate }\end{array}$ & $\begin{array}{l}\text { Normal, rapid mouse } \\
\text { respiration }\end{array}$ & $\begin{array}{l}\text { Slightly decreased } \\
\text { respiration (rate not } \\
\text { quantifiable by the } \\
\text { eye) }\end{array}$ & $\begin{array}{l}\text { Moderately reduced } \\
\text { respiration (rate at } \\
\text { the upper range of } \\
\text { quantifying by the } \\
\text { eye) }\end{array}$ & $\begin{array}{l}\text { Severely reduced } \\
\text { respiration (rate } \\
\text { easily countable by } \\
\text { the eye, } 0.5 \mathrm{~s} \text { between } \\
\text { breaths) }\end{array}$ & $\begin{array}{l}\text { Extremely reduced } \\
\text { respiration }(>1 \mathrm{~s} \text { between } \\
\text { breaths })\end{array}$ \\
\hline $\begin{array}{l}\text { Respiration } \\
\text { quality }\end{array}$ & Normal & $\begin{array}{l}\text { Brief periods of } \\
\text { laboured breathing }\end{array}$ & Laboured, no gasping & $\begin{array}{l}\text { Laboured with } \\
\text { intermittent gasps }\end{array}$ & Gasping \\
\hline $\begin{array}{l}\text { Rectal } \\
\text { temperature } \\
\left({ }^{\circ} \mathrm{C}\right)\end{array}$ & $36-38$ & $>38$ & $<36-\geq 35$ & $<35-\geq 34$ & $<34$ \\
\hline $\begin{array}{l}\text { Glycemia } \\
(\mathrm{mg} / \mathrm{dL})\end{array}$ & $\geq 148$ & $\leq 148-\geq 122$ & $<122-\geq 58$ & $<58->40$ & $\leq 40$ \\
\hline $\begin{array}{l}\text { Relative body } \\
\text { weight loss } \\
(\%)\end{array}$ & $0-5$ & $5-10$ & $10-15$ & $15-20$ & $>20$ \\
\hline
\end{tabular}

failure [24]. These dysfunctions cause tissue damage and impair brain function [25]. In our study, these neurological effects were reflected in the impairment of the level of consciousness and activity in the sepsis group (Figure S1A, C). The neurological symptoms can be identified in the first hours by MSS [13], but using the A-MSS allows the assessment of autonomic insufficiency evaluating the temperature (Figure 1(c)).

Neurohypophysial dysfunction promotes decreased hepatic gluconeogenesis-promoting adrenocortical hormones and liver and muscle glycogenolysis, causing a decrease in glycemia [26]. Furthermore, LPS is able to decrease the activity of hepatic and renal enzyme phosphoenolpyruvate carboxykinase (PEPCK) promoting gluconeogenesis and hypoglycemia [27], as observed in Figure 1(b).

Sepsis impairs neuroendocrine regulation by neuronal dysfunction impairing the secretion of vasopressor hormones (NASCIMENTO et al., 2017), accompanied by the desensitization of receptors for vasoconstriction [28]. Also, LPS and cytokines induce the nitric oxide production by macrophages, neutrophils, and monocytes [28]. Decreased cardiac output and blood pressure may be associated with hypothermia (Figure $1(\mathrm{c})$ ) $[13,29]$, reinforcing the need to measure body temperature in sepsis mouse models.

A catabolic condition leads to a reduction in muscle mass [30] is related to increased hospitalization period and mortality [16]. This metabolic effect is also verified in an experimental sepsis model $[11,12,31]$, and the results found in our study (Figure 1(d)) may be associated with muscle atrophy and lipid catabolism [32]. Also, leukocytes release interleukin-1 beta, which has a direct effect on appetite inhibition and food intake, reflecting in body weight loss [33].

The platelet function disorders play a crucial role in the pathophysiology of sepsis, with prognostic accuracy [34]. LPS and cytokine endotoxemia (tumor necrosis factoralpha (TNF- $\alpha)$, IL-8, IL-15) stimulate endothelium, 
monocytes, neutrophils, and basophils to secrete plateletactivating factor (PAF) [34]. PAF triggers platelet aggregation with the formation of microthrombi, which, together with leukocyte-induced hemophagocytosis [35], may result in decreased total platelet count (thrombocytopenia) and its relative rate [36]. Regarding MPV, it is already known that the $24 \mathrm{~h}$ period is insufficient for the increase in MPV to indicate the severity in patients with sepsis [37], as observed in our study (Figure 2(c)). It has been proposed that MPV indicates severity in just after 72 hours [38] and that the evaluation of MPV is insufficient to predict the worsening of sepsis due to peritonitis with gram-negative bacteria [17]. The dysfunction in the platelet count can also be observed by analyzing the ratios between the MPV and platelet count (MPV/PC), representing the risk of microthrombi formation [39]. The MPV/PC is a predictor of worsening of sepsis, specifically when it accuses the systemic infection with gram-negative bacteria [17], as we observed in our study (Figure 2(d)).

Immunosuppression observed by decreasing lymphocyte and monocytes leads to a decrease in total leukocytes (Figures 3(b)-3(d)). On the other hand, the bone marrow has a reservoir of neutrophils that are released into the circulation to combat infectious in the peritoneal cavity, as verified $12 \mathrm{~h}$ after sepsis induction [40]. Neutrophils are immune cells of the first line of defense against bacterial infection and may suffer exacerbated apoptosis in severe sepsis [17].

Studies suggest the application of NLR and PLR as inflammatory biomarkers [17]. PLR and NLR elevation is a prognostic marker of lethality in patients with peritonitis [17], as well as in an animal models [41], similarly to Figures 3(e) and 3(f). Also, platelet and immune biomarkers may indicate etiological agents [17]. Thus, the A-MSS proposed in our study was able to indicate sepsis in mice just after four hours, correlated with the 24-hour values of the biomarkers mentioned above: lymphocyte count, white blood cell count, platelet count, and NLR. These pieces of evidence allow proposing the A-MSS as a relevant tool for murine severe infectious diseases since it was able to predict the severity systemic dysfunction of the mouse sepsis model.

\section{Conclusion}

The A-MSS allows an early and more complete diagnosis of sepsis in mice and might be considered as a procedure to improve the analysis of systemic sepsis dysfunction in mice. The inclusion of new variables that can be directly measured represents the inclusion of objective criteria in a quite subjective exam to improve the accuracy of studies in mouse severe sepsis model.

\section{Abbreviations}

$\begin{array}{ll}\text { LPS: } & \text { Lipopolysaccharide } \\ \text { LTA: } & \text { Lipoteichoic acid } \\ \text { MSS: } & \text { Murine Sepsis Score } \\ \text { A-MSS: } & \text { Adapted Murine Sepsis Score } \\ \text { NaCl: } & \text { Sodium chloride }\end{array}$

ROC: Receiver operating characteristic

MPV: $\quad$ Mean platelet volume

MPV/PC: Ratio between MPV and platelet count

NLR: $\quad$ Neutrophil-lymphocyte ratio

PLR: $\quad$ Platelet to lymphocyte ratio

M-CASS: Mouse clinical assessment score for sepsis

SOFA: Sequential Organ Failure Assessment

CNS: Central nervous system

PEPCK: Phosphoenolpyruvate carboxykinase

iNOS: Inducible nitric oxide synthase

NO: $\quad$ Nitric oxide

IL-1 $\beta$ : Interleukin-1 beta

TNF- $\alpha$ : Tumor necrosis factor alpha

PAF: $\quad$ Platelet-activating factor.

\section{Data Availability}

All data will be available under request for authors.

\section{Additional Points}

Limitations. Our study did not use laboratory tests for sepsis evaluations such as bilirubin, creatinine, or lactate.

\section{Consent}

All authors approved the submitted and published versions.

\section{Disclosure}

A preprint version of this manuscript was also available in the Research Square online platform in the link https:// www.researchsquare.com/article/rs-64379/v1.

\section{Conflicts of Interest}

All authors declared that they have no conflict of interest.

\section{Authors' Contributions}

M.M.S. performed all of the experiments described in this manuscript with laboratory colleagues. M.M.S. performed the administration of fecal solution in the mice. The Murine Sepsis Score was evaluated by M.M.S. B.L.E.B., M.M.S., L.M.S., and K.O. performed the biometric and metabolic profile procedures. M.M.S. and L.M.S. performed the western blot analyses. M.N.F., W.F.A., and M.M.S. performed the hematological procedures. All authors were involved in analyzing the results. T.G.H., I.B.M.C., and M.M.S. performed statistical analyses and co-wrote the manuscript. T.G.H., M.S.L., and M.M.S. designed the study, provided experimental advice, and helped with manuscript revision.

\section{Acknowledgments}

The authors would like to thank all students from the Research Group in Physiology (UNIJUI) for his technical support. This work was supported by the Regional University of Northwestern Rio Grande do Sul State (UNIJUI), as well as by grants from the Research Support Foundation of 
the State of Rio Grande do Sul (\#ARD/PPP/FAPERGS/ CNPq 08/2014, process 16/2551-0000196-0 to TGH) and the Brazilian National Council for Scientific and Technological Development (CNPq) (\#MCTI/CNPq N ${ }^{\circ}$ 01/2016CNPq, process $407329 / 2016-1$ to TGH). MMS is the recipient of a scholarship from the Coordination for the Improvement of Higher Education Personnel (CAPES), and M.M.S., L.M.S., B.L.E.B., F.R.P., W.A., K.O., and L.W. were the recipients of a scholarship from UNIJUI, FAPERGS, and CNPq.

\section{Supplementary Materials}

\section{Supplementary 1. Table S1: Murine Sepsis Score (MSS).}

Supplementary 2. Figure S1: individualized MSS components, appearance, level of consciousness, activity, response to stimulus, aspect of eyes, respiratory frequency, and respiratory quality $(A-G)$ within 24 hours after induction of sepsis with $20 \%$ fecal solution $(1 \mathrm{mg} / \mathrm{g})$.

Supplementary 3. Figure S2: correlation between A-MSS four hours after induction and lymphocyte count, total leukocytes, platelets, and the ratios between neutrophils and lymphocytes (NLR), platelets and lymphocytes (PLR), and mean platelet volume and platelet count (MPV/PC) (A-F) within 24 hours after induction of sepsis with $20 \%$ fecal solution (1 mg/g).

\section{References}

[1] M. Meurer and K. Höcherl, "Endotoxaemia differentially regulates the expression of renal Ca2+ transport proteins in mice," Acta Physiologica, vol. 225, no. 1, article e13175, 2019.

[2] T. Skirecki and J.-M. Cavaillon, "Inner sensors of endotoxin implications for sepsis research and therapy," FEMS Microbiology Reviews, vol. 43, no. 3, pp. 239-256, 2019.

[3] D. G. Remick, A. Ayala, I. Chaudry et al., "Premise for standardized sepsis models," Shock, vol. 51, p. 4, 2019.

[4] S. Dutta and P. Sengupta, "Men and mice: Relating their ages," Life Sciences, vol. 152, pp. 244-248, 2016.

[5] S. Holtfreter, F. J. Radcliff, D. Grumann et al., "Characterization of a mouse-adapted Staphylococcus aureus strain," PloS one, vol. 8, no. 9, p. e71142, 2013.

[6] S. J. Parker and P. E. Watkins, "Experimental models of gramnegative sepsis," The British Journal of Surgery, vol. 88, no. 1, pp. 22-30, 2001.

[7] INSTITUTO LATINO AMERICANO DE SEPSE, Relatório Nacional: Protocolos Gerenciados de Sepse. São Paulo: [s.n.]. Disponível em, 2019, https://ilas.org.br/assets/arquivos/relatorio-nacional/relatorio-nacional-final.pdf.

[8] P. M. Grin, D. J. Dwivedi, K. M. Chathely et al., "Low-density lipoprotein (LDL)-dependent uptake of gram-positive lipoteichoic acid and gram-negative lipopolysaccharide occurs through LDL receptor," Scientific Reports, vol. 8, no. 1, pp. 111,2018

[9] Z. R. Stromberg, A. Van Goor, G. A. Redweik, M. J. Wymore Brand, M. J. Wannemuehler, and M. Mellata, "Pathogenic and non-pathogenic Escherichia coli colonization and host inflammatory response in a defined microbiota mouse model," Disease models \& mechanisms, vol. 11, no. 11, 2018.
[10] B. Shrum, R. V. Anantha, S. X. Xu et al., "A robust scoring system to evaluate sepsis severity in an animal model," BMC Research Notes, vol. 7, no. 1, pp. 1-11, 2014.

[11] M. M. Sulzbacher, A. B. Santos, R. D. Basso, G. E. Hirsh, M. S. Ludwig, and T. G. Heck, "Efeitos do tratamento com glutamina via enteral em modelo animal de sepse," Saúde (Santa Maria), vol. 44, no. 2, pp. 1-10, 2018.

[12] M. M. Sulzbacher, L. M. Sulzbacher, F. R. Passos et al., "A single dose of eHSP72 attenuates sepsis severity in mice," Scientific Reports, vol. 10, no. 1, p. 9198, 2020.

[13] S. H. Mai, N. Sharma, A. C. Kwong et al., "Body temperature and mouse scoring systems as surrogate markers of death in cecal ligation and puncture sepsis," Intensive Care Medicine Experimental, vol. 6, no. 1, p. 20, 2018.

[14] R. Tiruvoipati, K. Ong, H. Gangopadhyay, S. Arora, I. Carney, and J. Botha, "Hypothermia predicts mortality in critically ill elderly patients with sepsis," BMC Geriatrics, vol. 10, no. 1, p. 70, 2010.

[15] S. Park, D. G. Kim, G. Suh et al., "Mild hypoglycemia is independently associated with increased risk of mortality in patients with sepsis: a 3-year retrospective observational study," Critical Care, vol. 16, no. 5, p. R189, 2012.

[16] S. Auiwattanakul, K. Chittawatanarat, O. Chaiwat et al., "Effects of nutrition factors on mortality and sepsis occurrence in a multicenter university-based surgical intensive care unit in Thailand (THAI- SICU study)," Nutrition, vol. 58, pp. 94-99, 2019.

[17] D. Djordjevic, G. Rondovic, M. Surbatovic et al., "Neutrophilto-Lymphocyte Ratio, Monocyte-to-Lymphocyte Ratio, Platelet-to- Lymphocyte Ratio, and Mean Platelet Volume-toPlatelet Count Ratio as Biomarkers in Critically Ill and Injured Patients: Which Ratio to Choose to Predict Outcome and Nature of Bacteremia?," Mediators of Inflammation, vol. 2018, 15 pages, 2018.

[18] A. Kumar, D. Roberts, K. E. Wood et al., "Duration of hypotension before initiation of effective antimicrobial therapy is the critical determinant of survival in human septic shock," Critical Care Medicine, vol. 34, no. 6, pp. 1589-1596, 2006.

[19] C. Hoff, "Immoral and moral uses of animals," New England Journal of Medicine, vol. 302, no. 2, pp. 115-118, 1980.

[20] S. E. Bedell and B. T. Bush, "Erythrocyte sedimentation rate. From folklore to facts," The American journal of medicine, vol. 78, no. 6, pp. 1001-1009, 1985.

[21] R. T. Almeida, M. M. Almeida, and T. M. Araújo, “Obesidade abdominal e risco cardiovascular: desempenho de indicadores antropométricos em mulheres," Arquivos Brasileiros de Cardiologia, vol. 92, no. 5, pp. 375-380, 2009.

[22] E. P. Raith, A. A. Udy, M. Bailey et al., "Prognostic accuracy of the SOFA score, SIRS criteria, and qSOFA score for in-hospital mortality among adults with suspected infection admitted to the intensive care unit," JAMA, vol. 317 , no. 3, pp. 1644$1655,2017$.

[23] M. Singer, C. S. Deutschman, C. W. Seymour et al., "The third international consensus definitions for sepsis and septic shock (Sepsis-3)," Journal of the American Medical Association, vol. 315, no. 8, pp. 801-810, 2016.

[24] VIANA, R. A. P. P, Sepse para enfermeiros, Atheneu, São Paulo, 2 edition, 2013.

[25] J. Gasparotto, C. S. Girardi, N. Somensi et al., "RAGE mediates neurodegeneration in sepsis," Journal of Biological Chemistry, vol. 293, no. 1, pp. 226-244, 2018. 
[26] C. F. Pizarro and E. J. Troster, "Adrenal function in sepsis and septic shock Função adrenal na sepse e choque séptico," Jornal de Pediatria, vol. 83, no. 5, pp. 155-162, 2007.

[27] P. W. Caton, N. K. Nayuni, O. Murch, and R. Corder, "Endotoxin induced hyperlactatemia and hypoglycemia is linked to decreased mitochondrial phosphoenolpyruvate carboxykinase," Life Sciences, vol. 84, no. 21-22, pp. 738-744, 2009.

[28] VELASCO, F. P. DA S. E I. T, Sepse, Manole, Barueri (SP), 1st edition, 2007.

[29] C. F. Pinto, M. Watanabe, C. D. . Fonseca, C. I. Ogata, and M. . F. F. Vattimo, "A sepse como causa de lesão renal aguda: modelo experimental," Revista da Escola de Enfermagem da U S P, vol. 46, no. spe, pp. 86-90, 2012.

[30] C. Langhans, S. Weber-Carstens, F. Schmidt et al., "Inflammation-induced acute phase response in skeletal muscle and critical illness myopathy," PLoS One, vol. 9, no. 3, pp. 1-11, 2014.

[31] L. Xianchu, P. Z. Lan, L. Qiufang et al., "Naringin protects against lipopolysaccharide-induced cardiac injury in mice," Environmental Toxicology and Pharmacology, vol. 48, pp. 16, 2016.

[32] S. Al-Nassan and H. Fujino, "Exercise preconditioning attenuates atrophic mediators and preserves muscle mass in acute sepsis," General physiology and biophysics, vol. 37, no. 4, pp. 433-441, 2018.

[33] M. C. DO, M. J. Kluger, and A. J. Vander, "Suppression of food intake during infection: is interleukin-1 involved?," American Journal of Clinical Nutrition, vol. 42, no. 6, pp. 1179-1182, 1985.

[34] A. Bedet, K. Razazi, F. Boissier et al., "Mechanisms of thrombocytopenia during septic shock: a multiplex cluster analysis of endogenous sepsis mediators," Shock, vol. 55, no. 2, pp. 664-690, 2017.

[35] B. Francois, F. Trimoreau, P. Vignon, P. Fixe, V. Praloran, and H. Gastinne, "Thrombocytopenia in the sepsis syndrome: role of hemophagocytosis and macrophage colony-stimulating factor," The American journal of medicine, vol. 103, no. 2, pp. 114-120, 1997.

[36] F. Thiolliere, A. F. Serre-Sapin, J. Reignier et al., "Epidemiology and outcome of thrombocytopenic patients in the intensive care unit: results of a prospective multicenter study," Intensive Care Medicine, vol. 39, no. 8, pp. 1460-1468, 2013.

[37] F. Sadaka, P. L. Donnelly, M. T. Griffin, J. O’Brien, and R. Lakshmanan, "Mean platelet volume is not a useful predictor of mortality in septic shock," Journal of Blood Disorders \& Transfusion, vol. 5, no. 2, pp. 5-7, 2014.

[38] C. H. Kim, S. J. Kim, M. J. Lee et al., "An increase in mean platelet volume from baseline is associated with mortality in patients with severe sepsis or septic shock," PLoS One, vol. 10, no. 3, pp. 1-13, 2015.

[39] G. H. Oh, S. P. Chung, Y. S. Park et al., "Mean platelet volume to platelet count ratio as a promising predictor of early mortality in severe sepsis," Shock, vol. 47, no. 3, pp. 323-330, 2017.

[40] N. K. Hokama and P. E. Machado, "Interpretação clínica do hemograma nas infecções," Jornal Brasileiro de Medicina, vol. 72, pp. 38-49, 1997.

[41] H. F. Brooks, C. K. Osabutey, R. F. Moss, P. L. Andrews, and D. C. Davies, "Caecal ligation and puncture in the rat mimics the pathophysiological changes in human sepsis and causes multi-organ dysfunction," Metabolic Brain Disease, vol. 22, no. 3-4, pp. 353-373, 2007.
[42] N. N. Santos-Junior, L. H. Costa, C. H. Catalão, A. Kanashiro, T. Sharshar, and M. J. Rocha, "Impairment of osmotic challenge-induced neurohypophyseal hormones secretion in sepsis survivor rats," Pituitary, vol. 20, no. 5, pp. 515-521, 2017. 